\title{
INSTRUMENTALISM IN THE LAW OF TRUSTS - THE DisTURBING CASE OF THE CONSTRUCTIVE TRUST UPON AN EXPRESS TRUST
}

\author{
Charles Rickett
}

\begin{abstract}
New Zealand courts have begun to use the device of imposing a constructive trust over assets already held on trust under an express trust. This device raises a number of important issues about whether a doctrinally damaging analysis should be used to achieve what are clearly instrumental designs usually termed justice or fairness. This article examines the issues in depth and argues strongly that the device of a constructive trust on an express trust is illegitimate.
\end{abstract}

\section{INTRODUCTION}

The law of trusts in New Zealand is in a shambolic state. In this tiny jurisdiction we find the law of trusts being discussed in the context of strange beasts like sham trusts, alter ego trusts and illusory trusts. ${ }^{1}$ And in more recent times we now have the constructive trust on an express trust. These concepts have arisen largely in the context of what has become euphemistically known as "trust busting". This notion is essentially instrumental in the sense that its very existence is premised upon a need of some sort (not a legally doctrinal need, but a call for the achievement of "fairness" or because of an alleged imperative for social justice) to avoid the consequences of there being in the particular circumstances (of which a number have been discussed in the case law) a trust as opposed to there being no trust. The conceptual beasts either attack the very existence of the apparent trust, not on sound doctrinal grounds but largely through ex post facto policy justifications, or, in the

* Professor and Dean of Law, Auckland University of Technology. I wish to thank in particular Jessica Palmer and Mark Bennett for their helpful contributions to my thinking in this area. They are in no way responsible for the views I express or the confusion I continue to manifest.

1 It is notable that the leading text in this jurisdiction contains a separate chapter titled "Sham Trusts": see Jessica Palmer "Sham Trusts" in Andrew Butler (ed) Equity and Trusts in New Zealand (2nd ed, Thomson Reuters, Wellington, 2009) 394. The higher appellate courts have been seized of the beasts in recent times: see Official Assignee v Wilson [2008] NZCA 122, [2008] 3 NZLR 45; and Clayton v Clayton [2016] NZSC 29, [2016] 1 NZLR 551. 
subtler phenomenon I wish to deal with in this article, by appealing to an entirely alternative trust notion to circumvent the first apparent trust, thus setting up a collision between the two trusts within the jurisdiction of equity itself. There are also, as with any matter where fairness is invoked, in fact competing ideas of fairness at play here, which competition is actually submerged in the rather highly charged and emotive contexts in which the concepts are often argued.

A way of understanding the point I am making is to imagine analogous developments elsewhere in the private law. For example, posit a situation where either "gift busting" (perhaps more effectively named "gift gutting"?) or "contract busting" (perhaps better "contract crippling"?) were permitted, on the basis, in the first case, of the gift being undeserved because either the recipient was seen as already adequately materially wealthy or entirely undeserving for some other reason, say for just being horrible or being a male, of the donor's bounty; and in the second case, the contract was seen as improvident through a particularly paternalistic lens of, say, a judge who styles himself or herself an arbiter of the type of sensible behaviour required before the law will facilitate a party wanting to uphold the contract. Both these examples would mount a challenge to the wellestablished law for allowing people to regulate their own interpersonal relations worked out over centuries interstitially in the manner of the common law.

Most of the contents of the various trust busting concepts are doctrinally incoherent, and indeed rather than promoting fairness or justice actually actively promote interpersonal injustices. I think this is most obviously seen in the case of constructive trusts upon an express trust. I will seek to establish this in the following way. In Part II, I shall briefly outline the idea of the constructive trust on the express trust. Since this idea depends upon the mixing of two basic notions of trusts law, the next stage in the article must be to remind ourselves of how each of those notions operates and what it means. Accordingly, in Part III, I shall briefly outline what I understand to be the fundamental principles of the express trust. In Part IV, I shall do the same for constructive trusts, focussing on the particular type of constructive trust that is used in the constructive trust on the express trust doctrine. I will then conclude in Part V with my argument as to why the constructive trust on the express trust doctrine is both doctrinally unsound and, at its base, is founded on a view of fairness or justice that competes with that which underlies the private law doctrines of the constructive and express trusts.

\section{THE IDEA}

The social context of the idea has usually been the breakdown of marriage or civil union relationships and the consequent need to identify what relationship property exists for distribution to the two parties. ${ }^{2}$ It transpires that at some stage during the "togetherness" part of the relationship,

2 Torbay Holdings Ltd v Napier [2015] NZHC 2477, [2015] NZAR 1839 at [196]. This was not the context in which the idea received attention in Torbay Holdings. The defendant had misappropriated significant funds from the companies of which he was a director and the financial administrator. Funds had been embezzled in part by payments into a family trust account of which the defendant and his wife were trustees. Woolford $\mathrm{J}$ held that a constructive trust could be imposed over any property in the trust funds traceable to the stolen funds because the trustees had knowledge that these traceable funds were trust funds knowingly received by 
when in general terms things were going well, a trust has been expressly established whereby property has been transferred to trustees (who may include one or both of the relationship parties themselves) to be held on trust for beneficiaries (usually under a discretionary trust and often including one or both of the relationship parties as beneficiaries). On breakdown, the issue arises: how can the property, or at least some of it, held as trust property be recaptured into the relationship property pool? The answer developed over the last four decades has been either to bust the trust completely, or to circumvent its effects in some way. If a constructive trust property interest can be declared to be in existence in a way that trumps the express trust, then that property interest (in favour usually of the economically challenged party to the now broken down relationship) provides that party with a larger share of the overall property pie. So, in effect, the constructive trust breaks up (or busts) the express trust in pursuit of "fairness". The doctrine now has the imprimatur of the New Zealand Court of Appeal, most recently in Murrell v Hamilton. ${ }^{3}$ It is now spoken of amongst trust law practitioners in this jurisdiction as simply a part of the legal landscape of trusts. ${ }^{4}$ I assume that future generations of law students are being taught the doctrine now as if it were of the same stature as the three certainties. And so the shambolic thinking not only gets airplay but becomes bedded down as orthodox. Worse than that, I suspect this is seen as the cutting edge exciting stuff in the law of trusts, and is simply imbibed while "boring old stuff" is bypassed. If my reflections on what goes on at trusts conferences I have attended in New Zealand in 2014 and 2015 are accurate, then that is certainly how the growing bevy of trusts practitioners sees things!

Perhaps I might, as something of a dinosaur - a label that has been attached to me in several contexts - return at this stage to basic boring old principles?

\section{THE EXPRESS TRUST - WHAT IS IT?}

The doctrine of the express trust is not uncontested despite its antiquity. First, it can be said with confidence that its existence depends upon an expression of intention (objectively ascertained) by someone with the requisite capacity so to intend. ${ }^{5}$ Secondly, it is a concept that creates both in personam and in rem rights. The relevant rights belong to the beneficiaries and the relevant duties

the trust. There are considerable difficulties with his Honour's analysis, but for present purposes the point is simply that the constructive trust on an express trust idea has surfaced outside the relationship breakdown context.

$3 \quad$ Murrell v Hamilton [2014] NZCA 377, (2014) 3 NZTR 24-012.

4 Any person who attends a Society of Trust and Estate Practitioners (STEP) Conference or the biennial New Zealand Law Society (NZLS) Trusts Conference cannot but be confronted by the idea as if it were entirely orthodox. See for example several papers presented at the NZLS Trusts Conference in June 2015, notably Vanessa Bruton and Isaac Hikaka "Hot Topics in the Interaction Between Trusts and Relationship Property" (paper presented at the NZLS Trusts Conference, Auckland, 18 June 2015); and Ewan Eggleston and Simon Jefferson "How far can Trusts be Trusted When a Relationship Breaks Down: Frequently Asked Questions" (paper presented at the NZLS Trusts Conference, Auckland, 19 June 2015).

5 See Byrnes v Kendle (2011) 243 CLR 253. 
are owed by the trustee (as to both in personam and in rem duties) and the rest of the world (as to in rem duties). The in rem duties arise because the subject matter of the trust is property (of various kinds as recognised in law) which must be held by (with particularly limited in rem rights) the trustee for the beneficiaries (with other more beneficial in rem rights). The in personam duties owed by the trustee to the beneficiaries result from the range of express obligations included in the relevant expression of intention (the terms of the trust, expressed usually in a deed but also potentially orally) and default obligations generated both by the law of equity in its determination of the boundaries of the facilitative institution in question (for example, duties of strict compliance, duties of loyalty, duties of care and so on) and by statute. The legendary three certainties not only express the requirements for formation of the express trust but also mirror the very essence of such a trust: a relationship between trustee and beneficiaries in respect of property, in which both are legally interested.

What justifies the existence of the express trust is the intention of the settlor. It is that intention which brings the trust into being and which creates and/or enlivens the variety of duties and rights. The rights and duties are, in the language of Peter Birks, the responses to the event of intention. ${ }^{6}$ What is sometimes contested is the best way to understand the context in which the intention is expressed. Is the intention a unilateral one (the trust is equity's gift) or a bilateral one (the trust is equity's contract) $?^{7}$ This dispute has even worked its way into the debate about the sham trust! ${ }^{8}$ In my view, the best way to understand the express trust is as a unilateral gift by a dual ownership method. That is the only way to reconcile both the transfer to trustee on trust and the declaration of self as trustee as techniques of establishing a trust. Whichever version is preferred, if the trust mechanism is to work, the settlor (either unilaterally or through agreement with the trustee) must have some legal right (we call it ownership) in respect of the property the subject matter of the intended trust. Property owned by someone other than the settlor cannot be settled on trust. ${ }^{9}$ I cannot settle a trust in favour of my children of the money in your wallet. If you owe me money I can settle a trust of the debt because that debt is mine, but not of the money with which you intend to pay the

6 Peter Birks Unjust Enrichment (2nd ed, Oxford University Press, Oxford, 2005).

7 See JH Langbein "The Contractarian Basis of the Law of Trusts" (1995) 105 Yale LJ 625 at 626-642; David Hayton "Developing the Obligation Characteristic of the Trust" (2001) 117 LQR 96 at 105-107; Paul Matthews "The New Trust: Obligations without Rights?" in AJ Oakley (ed) Trends in Contemporary Trusts Law (Oxford University Press, Oxford, 1996) 1 at 22; and Patrick Parkinson "Reconceptualising the Express Trust" (2002) 61 CLJ 657 at 664-681. See also Korda v Australian Executor Trustees (SA) Ltd [2015] HCA 6, (2015) 255 CLR 62 at [9]-[10] per French CJ and at [108] per Gageler J.

8 See the debate between Jessica Palmer "Dealing With the Emerging Popularity of Sham Trusts" [2007] NZLR 81; and Matthew Conaglen "Sham Trusts" (2008) 67 CLJ 176.

9 This point was recently reiterated by the Court of Appeal in Bethell v Bethell [2014] NZCA 442, [2015] NZAR 1620 at [86] where an interest in property in respect of which $\mathrm{C}$ had an existing entitlement could not be granted by $\mathrm{R}$ - in whom legal title was vested - to M. I am grateful to Mark Bennett for drawing this case to my attention. 
debt! And whichever version, gift or contract, is preferred, once the trust is duly constituted and the property is in the legal ownership of the trustee (whether by transfer or by its nature as the settlor's own property at the time of the trust's declaration), the beneficiaries acquire property rights in equity in respect of those assets.

Or do they? Was I correct is suggesting earlier in this section of my article that express trusts create rights in rem? There is a further contested issue at this point: is an express trust a concept of obligations law or a concept of the law of property, or indeed a hybrid with bits of both? Is it true to say that the rights a beneficiary acquires are rights in rem over the property in the hands of the trustee ${ }^{10}$ Or is it more accurate to say that the beneficiary acquires rights over the rights in respect of the property which the trustee holds (that is some of the content which ownership implies belongs to the beneficiary)? ${ }^{11}$ In other words, while it is often loosely stated that the trust's greatest asset is its notion of split ownership, does that split occur in respect of different rights in rem over the same asset generated by the dual systems of common law and equity or of rights upon the rights rather than in the property? If the latter, can one talk about property at all, or is the trust really merely a complex web of obligational relationships ${ }^{12}$

Now at this point, and bearing in mind the contested nature of the beneficiaries' rights as just outlined, we must introduce another dimension that tends to throw a spanner in the works. Where the trust is a discretionary one (where the trustee has a duty to distribute in some form but a power preserving for him a discretion as to how and to whom to distribute trust assets), in what sense can it be said that there are rights in rem in the beneficiaries? No discretionary beneficiary (someone who might or might not be chosen by the trustee at the latter's discretion to receive a distribution of the trust assets) has a claim to own the trust property - at best, she can say "I hope or expect to get something when the discretion is exercised". That is true, but it does not help us answer a question that must be answered. Assume a trust fund held by the trustee as trustee. The trustee has rights in rem in the fund, but his particular rights do not extend to the beneficial part of any rights in rem since such an extension would be inconsistent with his role as trustee! For example, unlike the nontrustee legal owner, he cannot possess the trust property. His role as legal owner is to transfer the trust property to those entitled to it and, in the meantime, manage it in such a way that he will be able to execute the transfer when the time comes. If the beneficiaries as individuals are not able to claim the benefit of the property (by whichever of the routes outlined in the preceding paragraph),

10 As seems to be the orthodox understanding: see for example the entire tenor of their Lordships' speeches in Foskett v McKeown [2001] AC 102 (HL). See also JE Penner "The (True) Nature of a Beneficiary's Equitable Proprietary Interest Under a Trust" (2014) 27 CJLJ 473.

11 See Lionel Smith "Trust and Patrimony" (2008) 38 RGD 379; and Ben McFarlane and Robert Stevens "The Nature of Equitable Property" (2010) 4 J Eq 1. See also the very full discussion and critique in Penner, above $\mathrm{n} 10$.

12 See the full discussion of this matter in Penner, above n 10. 
and the trustee cannot do so either, then where exactly is the beneficial ownership? Three possibilities come to mind: first, there is no beneficial ownership (which seems to me to give rise as a creation of equity to the very thing which equity claims to abhor, a vacuum in the beneficial ownership); secondly, the beneficial ownership exists but is suspended as it were until the trustee's discretion is exercised (which seems at first sight a defensible approach given that equity acknowledges suspension of beneficial ownership in some of its cuter corrective doctrines such as secret trusts and mutual wills but which on reflection looks somewhat at odds with the more central doctrine of that subclass of express trusts known as discretionary trusts ${ }^{13}$ ); and thirdly, the beneficial ownership is held by the whole body of discretionary beneficiaries as a body (which has not been canvassed to my knowledge in the case law and which is made more difficult by the softening of the certainty of objects test from the all individuals or list certainty test articulated most forcefully by the Court of Appeal of England and Wales in Inland Revenue Commissioners v Broadway Cottages Trust ${ }^{14}$ to the criterion certainty or any individual test adopted by the House of Lords in McPhail v Doulton. ${ }^{15}$

If the third view is taken, then it is entirely possible to argue that even in the case of a discretionary trust the beneficiaries acquire vested rights in rem at the point of the trust's creation. ${ }^{16}$

13 See for example CEF Rickett "A Rare Case of Mutual Wills and its Implications" (1982) 2 Adel L Rev 178; CEF Rickett "Mutual Wills, Restitution and Constructive Trusts - Again" [1996] Conv 136; and CEF Rickett "Thoughts on Secret Trusts From New Zealand" [1996] Conv 302. The mutual wills "floating trust" has recently received recognition in an obiter dictum in New Zealand; Chambers $v$ Chambers [2016] NZHC 583 at [122].

14 Inland Revenue Commissioners v Broadway Cottages Trust [1955] Ch 20 (CA).

15 McPhail v Doulton [1971] AC 424 (HL).

16 Penner, above n 10. Penner comes close to suggesting this, although he is not expressly addressing this point, when he states of the trust beneficiaries' rights, at 490 (emphasis added):

... the beneficiaries are not mere claimants in respect of the trust assets whose claims the trustee might conceivably "discharge" so as to become the unencumbered legal owner himself. That is not the correct way to understand the trust beneficiaries' rights. They are, collectively, the beneficial owners of the trust assets.

It is not clear to me that a different understanding of the beneficiaries' rights in a discretionary trust would be proffered so as to "de-power" (a rugby term applied to golden oldies scrums) the trust! Indeed, later, at 495-496, Penner concludes his argument about the nature of a beneficiary's beneficial interest with a statement that "the discretionary trust [is] perfectly compatible with the concept of 'beneficial interest'". His point, at 495, essentially is that beneficial interests are not possessory interests:

$\ldots$ it is not essential to a trust, or to the conception of a beneficial interest under a trust, that any object has any immediate, vested interests in the trust assets. ... [A]ll beneficial interests under trusts ... are essentially future interests in the sense that they require the trustee to exercise his power of transfer to transfer the legal title to trust assets to the objects ... The essential point to notice here is that the trustee can hold trust assets not to his own benefit yet at the same time so that the benefit will enure only to the benefit of others on a future, contingent basis. Those future and 
A similar consequence could follow from the second argument: the beneficiaries acquire floating rights in rem. I discount the first argument as incoherent. ${ }^{17}$

The important points to conclude on at this point are that an express trust creates rights in the beneficiaries. These rights cease to be rights in any legally meaningful sense if they can be dealt with by others in a manner inconsistent with their very nature and scope.

\section{THE CONSTRUCTIVE TRUST - WHAT IS IT?}

If the express trust remains contested in some minor respects, then the constructive trust remains a mystery bedevilled by its apparent simplicity and its beguiling appeal. Apart from the hopeless terminological problems in the area - which I attempted many years ago to cut through, but sadly without too much success - there remains a continuing infatuation with the idea that constructive trusts are imposed by courts on the basis of hopelessly flawed criteria such as unconscionability and unjust enrichment at an abstract level - which again I tried to confront in my earlier article. ${ }^{18}$

In referring in the present article to constructive trust I am not referring in any way to three of the uses of that term I identified in my earlier article - being constructive trusts after a tracing exercise which reveal equity's doctrine of overreaching, ${ }^{19}$ or constructive trusts of the remedial type which are court ordered and thus truly imposed proprietary remedies, ${ }^{20}$ and so-called constructive trusts over third parties who have assisted in a breach of trust or received trust property from a trustee in breach with the requisite knowledge (which are actually cases of personal liability). ${ }^{21}$ The

contingent interests absorb all the benefit the assets have. Thus it is a mistake to confine the notion of beneficial interest to presently vested or indefeasible interests ...

17 It is quite possible that some sense could be made of the first position in the context of the right in a right view of the trust but I agree with Penner that that view is incoherent - in other words it is merely to delay in the analysis the incoherence of the first position! See Penner, above n 10.

18 See CEF Rickett "The Classification of Trusts" (1999) 18 NZULR 305.

19 See Foskett v McKeown, above n 10.

20 See Fortex Group Ltd (in rec and liq) v MacIntosh, Cox \& Forde [1998] 3 NZLR 171 (CA).

21 See Torbay Holdings Ltd, above n 2, where in dealing with personal liability for knowing receipt Woolford $\mathrm{J}$ appeared to think that the liability in knowing receipt gave rise to a proprietary constructive trust as an immediate consequence of that liability. His confusion arose in respect of claims against the defendant and his wife as trustees. Woolford J suggested, at [197], that knowing receipt gave rise to personal liability to account, whereas, at [196], the analysis was in terms of imposing a constructive trust over an express trust; rather bemusingly his Honour stated, at [196]:

A finding of knowing receipt against the Trust [I interject to ask how a legally non-existent entity can be liable for anything at all] means that, if the money can be traced into new property purchased by the Trust [I interject to say that this assumes that there was something to trace in the first place - that was the interest of the plaintiff companies in the institutional constructive trust over the misappropriated funds - and therefore the trust has nothing to do with knowing receipt liability but is an orthodox application of Foskett v McKeown principles], a constructive trust would 
constructive trust in focus here is what is often called a Lankow $v$ Rose-type trust. ${ }^{22}$ This is a constructive trust recognised - and I use that word deliberately - by the court after the evidence establishes four criteria that must be and are on the evidence satisfied:

(1) contributions, direct or indirect, to the property in question;

(2) the expectation of an interest in the property;

(3) that such expectation is a reasonable one; and

(4) that the defendant should reasonably expect to yield the claimant an interest. ${ }^{23}$

It is an institutional constructive trust in the sense that the court looks into the past and is asked to identify that a trust came into existence by the actions of the parties at some point prior to the hearing itself. What brings the trust into being and hence justifies it is not the court's order (just as in a case where the court is asked to decide whether there has been an effective declaration of express trust in the past it is not the court's order but the adequate expression of intention by the settlor party that brings the trust into existence). Indeed, the institutional constructive trust is the only form of constructive trust which lives up to its name of having been construed by the court from the evidence of intentions around the activities which "created" it. ${ }^{24}$ The real reason the trust comes into being is that it was the intention of the settlor party that it do so. The fact that the settlor party is now trying to retreat from the trust is not a doctrinal difficulty because the trust has already come into existence well before that attempted retreat takes place. ${ }^{25}$ The consequence of an institutional

exist over that new property [I interject again to say that this must be a Foskett-type constructive trust].

It is simply not clear that a knowing receipt claim gives rise to a constructive trust. There is often confusion in the cases between a proprietary claim based on a pre-existing proprietary interest which is traceable into the hands of a receiver of that property or its substitute and results automatically in the recognition of a constructive trust and a personal claim in knowing receipt which results in personal liability as if the receiver were a constructive trustee but which does not result in a constructive trust. In Torbay Holdings, above $\mathrm{n} 2$, there was no need to go as far as to suggest personal liability of the trustees (where if found to exist a further jump would need to be made to create a proprietary remedy over the assets held on trust hence the notion that what was at issue was a constructive trust on an express trust) because when the trust assets had mingled with them the misappropriated funds (those latter funds being trust funds already belonging to the companies), the latter were never the property of the beneficiaries of the express trust and, if traceable, they or their substitute could be regained by their rightful beneficial owners - this was not a constructive trust being imposed on an express trust but a simple recognition that the funds and substitutes claimed were property which always belonged to the companies.

22 Lankow v Rose [1995] 1 NZLR 277 (CA).

23 At 294 per Tipping J.

24 For a much fuller treatment of this argument see Rickett, above n 18. See also Jessica Palmer "Attempting Clarification of Constructive Trusts" (2010) 24 NZULR 113; and Jessica Palmer "Constructive Trusts" in Andrew Butler (ed) Equity and Trusts in New Zealand (2nd ed, Thomson Reuters, Wellington, 2009) 335.

25 I have long regarded the Privy Council's decision in Attorney-General for Hong Kong $v$ Reid [1994] 1 NZLR 1 (PC) as a classic case of this type. It is certainly not an example of a constructive trust being 
constructive or construed trust is that the constructive trustee holds the property on a bare trust for the identified constructive beneficiary who acquires in rem rights in respect of that property. The only effective duty on the trustee is to transfer the property to the beneficiary as soon as that beneficiary is known and/or requests such transfer.

Now there is one point that needs to be made. The point is so obvious that it has gone unarticulated, but the notion of a constructive trust on an express trust now requires its articulation. In an argument for an institutional constructive trust of the Lankow $v$ Rose type, the party yielding the beneficial interest in the property in question to the claimant (as Lankow requires) must surely have such an interest to yield in the first place? If I am trustee of house $\mathrm{X}$ for $\mathrm{B}$, then how can anything I do or intend yield a beneficial interest in that house to $C ?^{26}$ That would be me stealing from $\mathrm{B}$ to give to $\mathrm{C}$. Were the court to countenance that, it would be complicit in the theft. That is surely unimaginable - but not, it appears, in New Zealand!

\section{A The Problem of Unjust Enrichment}

In a general sense, of course, the circumstances that Lankow $v$ Rose deals with can be characterised as cases where there would be an unjust enrichment to the defendant as a result of the contributions to the property which inhere to the defendant unless the latter is required to give them up. This in itself does not warrant a claim in unjust enrichment. Merely asserting an enrichment given does not mean that the enrichment received was unjust. There is no clear unjust factor creating in the claimant a defective subjective consent of the type required to taint the enrichment with

imposed by the court as a remedy to avoid some type of unconscionable activity, although there was clearly nefarious activity in the case. Reid could not hang on to the bribes he had taken (or their substitutes) because by taking on his particular position he had agreed that he would not take bribes - and I suggest by obvious implication that if he did take bribes he would hold them for the Hong Kong government. Hence the case was about how to deal with his obvious reneging on that position - not with his taking of the bribes per se!

26 Penner, above n 10, makes the same argument in this way, at 491:

... even where, in the purported exercise of a power to create a new settlement, the trustee successfully transfers trust assets to a different person, the recipient "trustee" does not hold those assets for the new settlement but subject to the beneficiaries' rights under the old one; rather, the exercise does nothing to affect ... those beneficiaries' rights. The recipient is merely a recipient of trust property transferred in breach of trust, and the only equitable interests in the trust assets are those of the original beneficiaries. A fortiori, a trustee declaring a trust of the asset he holds in favour of some third party, when he has no power to do so under the terms of the trust, does nothing at all. Such a declaration would be no more effective to displace B's interest under a trust than would my contract to sell you London Bridge displace the interest of whoever has title to that. I have no power to sell London Bridge because I don't own it, and the trustee has no power to declare a trust of assets in which, in the eyes of equity, he has no beneficial interest.

Given that an institutional constructive trust of the Lankow $v$ Rose type on an express trust is founded upon the creation of the asserted constructive trust by the trustee, the same analysis holds true in that case as in the one raised by Penner. 
unjustness unless one pleads mistake in making the contribution or a failure of the basis upon which the enrichment was transferred. ${ }^{27}$ Either argument seems unlikely to be present in a relationship context where love and selfless giving is the usual hallmark. In any event, it is not at all clear that a proprietary remedy - which is after all the claimant's objective - will lie for a claim in unjust enrichment except potentially in the persona of a resulting trust which has been tried in this area and found wanting. ${ }^{28}$

There is an intriguing passage in the Court of Appeal's judgment in Murrell v Hamilton which calls for comment and it seems apposite to discuss it at this point. The Court in that case upheld a constructive trust on an express trust and stated: ${ }^{29}$

We emphasise that allowing Ms Murrell's claim [based on Lankow v Rose] does not alienate Trust property [namely the property held in the express trust], that is it does not take away from the beneficiaries of the Trust something to which they are entitled. Rather, it means a part of the value of the Trust's property which should not accrue to the Trust does not accrue to it. Allowing Ms Murrell's claim averts the unjust enrichment which would otherwise result to the Trust - essentially the Trust getting $\$ 37,500$ for nothing - a windfall.

With the greatest respect, the sophistry in this passage is indicative of the type of shambolic reasoning which in my view can only be defended as naked instrumentalism. Let me illustrate. First, there is no such entity as "the Trust" in our law, unless a statute has slipped through Parliament but has gone unnoticed and which turns all private trusts into juristic persons! The trust cannot own property or receive value in its own right. ${ }^{30}$ It cannot thus receive an unjust enrichment. Secondly, the dichotomy between value and assets is misplaced. Those who are beneficially interested in the trust property or assets can only acquire value because of or through those assets, or by the receipt of more assets. It is correct that the law of unjust enrichment is concerned with restoration of value received by one at the expense of the other, but that value is located in the assets transferred (or perhaps in the services rendered (although this point is hugely contested ${ }^{31}$ ). To order the trustees to pay $\$ 37,500$ to Ms Murrell does not require, it is true, that the beneficiaries of the express trust must be dispossessed of assets that would otherwise be theirs, but it does require the liquidation of those assets in order to find the value of which the trust is to be deprived - which is then paid over in the form of liquid cash assets $(\$ 37,500)$ to Ms Murrell. Of course, it is likely that the trustees would

27 See Ross Grantham and CEF Rickett "On the Subsidiarity of Unjust Enrichment" (2001) 117 LQR 273

28 Ross Grantham and CEF Rickett Enrichment and Restitution in New Zealand (Hart Publishing, Oxford, 2000) at 416-417.

29 Murrell v Hamilton, above n 3, at [30].

30 See also my comment on Torbay Holdings Ltd, above n 21.

31 See generally Grantham and Rickett, above n 28, at 61-63, 146-147, 165-167, 172-175, 225, 244-248 and 266. 
fund the payment of value by paying over cash they hold in a bank account, but that is clearly taking away from the beneficiaries something to which they are entitled. Perhaps a better way of locating the source of Ms Murrell's right to a payment under the Lankow v Rose formulation is to say that she will receive remuneration for services rendered to the trustees in the form of a near contract arrangement, in effect the payment is compensation not restoration. ${ }^{32} \mathrm{~A}$ third observation to make is that the appeal by their Honours to unjust enrichment in the comments quoted above is no more than an appeal to a general (moral) principle to justify taking from the beneficiaries in order to give to Ms Murrell. It is a naked instrumental use of the supposed moral appeal.

A fourth observation is that the Court reveals the thread of confusion that runs through Lankow $v$ Rose jurisprudence. While I characterised it earlier as the creation of an institutional constructive trust, it transpires that more often than not it results only in an order to pay the claimant a sum of money, or a personal order. That consequence does make one wonder whether in fact Lankow $v$ Rose is more properly to be seen as a part of the law of unjust enrichment, as these types of cases are in fact dealt with in Canada. ${ }^{33}$ Two observations follow from that wondering. First, some careful analysis of an unjust enrichment understanding of Lankow $v$ Rose is needed from within the structure and confines of the law of unjust enrichment. That is not the purpose of this article, although I intend to return to it in due course. Secondly, the rather depressing consequence of this suggestion is that we might have to take more seriously than we want to the developments in the Canadian courts - always something to be wary about! However, the upshot of such a movement would be to avoid the conflict between express and constructive trusts altogether and to replace that with a jurisprudentially sound focus on the rights and duties of the relevant parties to the various relationships as between themselves without affecting other third parties.

\section{A RED HERRING}

One important consequence of the development of the idea of a constructive trust on an express trust is that if the express trustees are to yield an interest as trustees over the assets they hold as trust property, a question arises: since they are dealing as trustees must they act unanimously in order to bind the property or is the activity of one trustee enough? We should note two things. First, this point is entirely different from the point as to non-owners being able to "give away" property belonging to others. Secondly, a focus on this point is a red herring unless it reveals a sense of concern about the legitimacy of the whole development of the idea of constructive trust on an express trust. I posit that it is in fact to be explained as an attempt to rein in the idea - almost as if a sense of unease is being felt as to the potential reach of the idea. The genie is out of the bottle and

32 At 266

33 See Kerr v Baranow 2011 SCC 10, [2011] 1 SCR 269. 
this seems a way to try and put at least some of it back in the bottle. The unease of the Judge in Vervoort $v$ Spears is palpable. ${ }^{34}$ Reflecting on point (4) in the Lankow test, Ellis J stated: ${ }^{35}$

But because a constructive trust will not arise over property unless it is reasonable for the property owner to yield an interest in it, it has been held necessary for a claimant to prove that all trustees agreed to acquiesce in that respect. And since trustees must act unanimously and may not delegate their trustee duties, the representations or conduct of one trustee cannot bind the trust as a whole and the other trustees cannot be bound by a general delegation.

There had not on the facts before her been any "specific agreement or discussion between the trustees about [the claimant] obtaining an interest in the [trust property]", and her Honour thus concluded that there was no constructive trust of the express trust. ${ }^{36}$ The courts have got themselves into a pickle here - and a shambolic one. Rather than confronting head on the inadequacy of the very idea of a constructive trust on an express trust, they are now using or not as the case may be (and it all seems to boil down to the well-known mantra of distinction on the basis of "peculiar facts") a fundamental principle of trust law to save the law from becoming a complete ass! That is why I call this focus a red herring! But let us return to the central argument and focus of this article.

\section{THE DOCTRINAL UNJUSTNESS AND INCOHERENCE OF THE NOTION OF A CONSTRUCTIVE TRUST ON AN EXPRESS TRUST}

Let us start by recalling that an express trust provides beneficiaries with rights of some type exigible against the assets held by the trustees. So the trust assets are beneficially owned in some way by the beneficiaries. Furthermore, even discretionary beneficiaries have proprietary rights in this respect. On the other hand, the trustees also have rights in the trust property but these rights are very limited indeed. It is unlikely in fact that - subject only to overreaching - the trustee can alienate rights or even create rights in those rights in others. Nemo dat quod non habet might be a Latin way of making the point! So a trustee cannot reasonably expect to yield to another person an interest the trustee does not have a power to yield! To allow a trustee or trustees, without an express power to do so, to yield merely by their conduct a beneficial interest in the trust property to someone who thereby becomes in effect a new beneficiary is unthinkable in the equity jurisdiction. For a court to sanction such a result by imposing a trust to achieve it is to fall into the "cry equity" trap I have discussed elsewhere. ${ }^{37}$ It is not only instrumentalist and therefore doctrinally incoherent, but it

34 Vervoort v Spears [2015] NZHC 808, [2015] NZFLR 525.

35 At [73] (citations omitted).

36 At [82]. Her Honour was forced to distinguish the apparent refusal of the Court of Appeal in Murrell v Hamilton, above $\mathrm{n} 3$, to apply the unanimity rule to decline a constructive trust on the basis that the Court in that case saw the facts as "somewhat peculiar": at [79].

37 See Charles Rickett "Cry 'Equity' - It Works!" [2013] NZLJ 25. 
is in fact in itself to sanction unjustness. The only interest the trustee can yield is an interest in property belonging to others. That is to create a liability in others who may well not be in any way responsible and at the same time to steal from some to give to another. It is Robin Hood law. It is the kind of law that exists in some parts of the world, like Zimbabwe, but it must not be allowed to creep into New Zealand, no matter how appealing the instrumental reasoning that accompanies it might at face value seem. The rule of law is not only a signal theme of public law but private law enhances it and is reliant on it. The rule of law is a system of justice. It takes rights seriously. When courts start to ignore rights and rule on the basis of intuitions of fairness and unconscionability and so on, we move away from justice to regulation. ${ }^{38}$

In addition to what I have already said, the constructive trust on an express trust doctrine creates an internal incoherence. First, equity recognises rights and duties on the basis of the expressed intention which results in the express trust. This is to do the conscionable thing, because the conscience of the trustee is bound by the trust. ${ }^{39}$ Secondly, equity then, having created by its recognition a right to property and in effect given it the status of a property right, is invited to dismantle its own creation by redistributing rights to the property in a different way. It is asked to fill in a gap where, on its own terms, there is no longer a gap since it has already filled it in. This is not the same as being asked to supplement the common law or fill in a gap created by the common law. Equity is forced into an internal battle - and that destabilises the very foundations of equity.

Realise what I am not saying. I am not saying that in the breakdown of marriage and civil union relationships there is no real world problem with all its social and economic angles. But I am saying that the present way in which our courts are persuaded to deal with it is disturbing. Furthermore, I am not saying that there is no answer to the problem. I think it may well be that the answer, if counsel and the courts wish to persist in trying to solve the problem, lies in the law of unjust enrichment. As Peter Birks used to say, in another dimension, given enough time, the willingness to work hard and access to a good law library, the issue whether a particular purpose was properly one beneficial to the community in the law of charity could be worked out as a legal question. ${ }^{40}$ I think the same is true here. That is, in fact, the genius of the Common Law (here I intend to include

38 This is why the notion of interpersonal justice is crucial to an understanding of private law. If that kind of justice is forgotten, it is and can only be replaced by an appeal to the interests of the State, which are generally interests in regulating their subjects! See Allan Beever Forgotten Justice: Forms of Justice in the History of Legal and Political Theory (Oxford University Press, Oxford, 2013).

39 See Rohan Havelock "The Evolution of Equitable Conscience" (2014) 8 J Eq 128; and Rohan Havelock "Conscience and Unconscionability in Modern Equity" (2015) 9 J Eq 1.

40 I have been unable - not I admit through want of trying - to locate the comment in its published form so I am forced to plead my hearing it in a tutorial I had with him sometime between 1972 and 1975. It is a comment that has stayed with me since I first heard it! 
equity) and the proper role of the legal academic. ${ }^{41}$ Alternatively, of course, we might want to despair of that possibility and hand the matter over to law reform bodies and the Parliament for statutory resolution. It seems that might indeed be a possible panacea in New Zealand for the relationship property problem. But whatever we do, creating a shambles in the well thought out and case hardened law of trusts is not an outcome we should relish. Indeed, it is a prospect that private lawyers in particular should be critically and conscientiously concerned about. For soon, if the rot continues, we will have nothing to say because there will be nothing to talk about.

\section{ADDENDUM}

I am grateful to the editor for indulging my request to add by way of an addendum to my article, before its final publication, some comments on two recent Court of Appeal judgments which have, sadly in my view, further entrenched "the disturbing case" in the positive domestic law of New Zealand. These cases were decided after the article was written, and indeed the article in manuscript was read and referred to by the members of the Court in the first case, Vervoort v Forrest ${ }^{42}$ without in any way, it appears, having persuaded the learned members of that Court to avoid a continuation of the doctrinal error. Rather oddly, however, the Court has in fact, in my view, actually made my fundamental case for me, as I shall endeavour in these comments to show; that is, that in New Zealand we are now beset with rampant instrumentalism that threatens to overwhelm the doctrines of trust law. In the second case, Hawke's Bay Trustee Co Ltd $v$ Judd, ${ }^{43}$ where judgment was given 13 days after Vervoort in a differently constituted Court, Vervoort was essentially cited as having settled the matter.

I referred to the High Court decision in Vervoort in my article under the heading "A Red Herring". ${ }^{44}$ Ellis $\mathrm{J}$ had avoided recognising a constructive trust on an express trust by taking refuge in the fundamental trust law principle requiring unanimity of action before trustees could in any way effectively dispose of trust property. Since there were two trustees and the second trustee had not been active and therefore could not in any way have had an expectation of yielding an interest to the claimant, the trustees were not acting unanimously. My point was that this focus on the unanimity rule is a red herring because it assumes that there is a legitimate possibility of a constructive trust on an express trust in the first place, which I was arguing was not so.

The Court of Appeal was faced first, rather ironically, with the argument that the express trust was a sham, and was pretty firm in its rejection of that argument (and of the similar argument that

41 I have already expressed in print my view of the academic role in Common Law legal scholarship: see Allan Beever and Charles Rickett "Interpretive Legal Theory and the Academic Lawyer" (2005) 68 MLR 320.

42 Vervoort v Forrest [2016] NZCA 375, (2016) 4 NZTR 26-017.

43 Hawke's Bay Trustee Co Ltd v Judd [2016] NZCA 397.

44 See the text above, accompanying n 34. 
the trust was an illusory trust). It was also not prepared to countenance any more subtle argument that if not a sham at its inception the trust became a sham at some stage after its inception (an "emerging sham"), stating: ${ }^{45}$

It may be a situation could arise when an originally valid trust becomes a sham because there has been a deliberate change in the trust arrangement so that it no longer has any of the characteristics of a trust, and the use of the trust name has become a deliberate pretence of a trust arrangement. However, there are conceptual difficulties with this, summarised by Jessica Palmer in her article "Dealing with the Emerging Popularity of Sham Trusts", and we do not need to determine the question in this appeal. ...

[T] he trust in fact did continue to own all the assets and show the features of a trust.

I say that this is rather ironic because the Court's later willingness to sidestep rather blatantly the consequences of there being a legitimate express trust in the first place sits at odds with the strong appeal to the characteristics and features of a trust (which appear to have been taken as read rather than articulated anew) in order to dismiss the first argument of the claimant/appellant.

The Court then confronted the constructive trust on an express trust argument. The motivation for such a claim was expressly recognised: ${ }^{46}$

Where one partner has de facto control of the trust and Lankow $v$ Rose contributions and expectations

have arisen the non-controlling partner may be forced to claim against the trust itself if any share of the assets is to be obtained.

Later the Court stated that in a number of decisions it had "been accepted that, in a family context, there could be a constructive trust arising in relation to property owned by an express trust". 47

In fairness to the Court it must be noted that the respondents had made no appearance in the appeal, and so the Court was left to its own devices, first, to identify the two objections to the constructive trust analysis, and, secondly, to express its view on these objections.

The first objection was the lack of unanimity of the trustees, and the prohibition on trustee delegation. ${ }^{48}$ The Court gave this short shrift in four paragraphs, the first three of which are worth reproducing in full: 49

45 Emphasis added; citations omitted.

46 At [48].

47 At [51] (emphasis added).

48 At [61].

49 Emphasis added; citations omitted. 
[62] We are respectfully unable to agree with this reasoning. The Judge was quite right in acknowledging the traditional trust principles of unanimity and non-delegation, but those principles must bend to the practical realities when one trustee is in absolute control of all trust activities and the other trustees have effectively abdicated their trustee responsibilities. Any other conclusion would mean settlors, who appointed themselves as trustees, would be able to take advantage of their own wrong in failing to ensure the trust is properly administered by all trustees. The trust would get a windfall, not available but for the use of the trust format.

[63] While traditional trust principles require unanimity and non-delegation, the Court's approach to trusts must, as the recent cases show, meet the reality of how property is owned in New Zealand. In 2013 there were estimated to be between $300,000-500,000$ private trusts in New Zealand. It seems likely a good portion of New Zealand's real estate is now held in discretionary family trusts of the same type as the trust created in this case.

[64] Prime v Hardie, Glass v Hughey, Marshall v Bourneville and now Murrell v Hamilton can be seen as the application of established Lankow $v$ Rose principles to this reality. In a case like this, where one relationship partner is in control of the trust, under the present state of New Zealand law there is a valid trust. However, that controlling partner cannot avoid equitable constructive trust obligations by relying on the prohibition on delegation and the lack of consent from the other trustee, whom that controlling partner has deliberately isolated from trustee functions. To allow that would be to allow a trust principle to operate as a weapon for inequity. The deliberate exclusion of other trustees from a role in managing the trust cannot be invoked to create an injustice.

What do these comments reveal? I think they clearly show that instrumentalism is running rife here. As I stated in my article, I acknowledge there is a social problem present on the factual matrices of these cases, but I frankly do not believe that merely discounting - or worse still wrecking - basic long-settled principles of trust law, worked out over centuries on the anvil of hard cases, is the way to deal with the problem. Apart from any incoherence such an approach creates within the law of trusts, it has serious consequences that have simply not been thought out. Let me make the point this way. On 19 August 2016, Lord Neuberger gave an address at a conference in Singapore dealing with protection of business and economic interests, during which he stated: ${ }^{50}$

That issue [the wider issue he had identified as he came to prepare his paper on principles governing the law of torts] is whether judges should decide tort cases by applying the established principles to the facts of those cases, or whether they should decide such cases by reference to what they see as the appropriate policy considerations as applied to those facts.

50 Lord Neuberger, President of the Supreme Court of the United Kingdom "Some Thoughts on Principles Governing the Law of Torts" (Distinguished Guest Speaker Lecture, Singapore Conference on Protecting Business and Economic Interests: Contemporary Issues in Tort Law, Singapore, 19 August 2016) at [2]. 
I do not think there can be any doubt on which side of the divide the members of the Court who decided Vervoort stand. John Smillie's notion of juristocracy comes to mind here too. ${ }^{51}$

There is a bit of a postscript to the comment of Lord Neuberger quoted above. While Lord Neuberger was happy to embrace a policy-based approach in his perspectives on tort law when speaking in Singapore, he had almost two years earlier to the day given a paper in Queenstown, New Zealand, at a Banking and Financial Services Law Association (BFSLA) conference, on the remedial constructive trust in which his Lordship appeared to adopt the application of the established principles approach. He stated: 52

There is much to be said for the notion of a remedial constructive trust displays equity at its flexible

flabby worst. I will seek to show, at least arguably, that it is unprincipled, incoherent and impractical,

that it renders the law unpredictable, that it is an affront to the common law view of property rights and

interests, that it involves the court usurping the role of the legislature, and, as if that were not enough,

that the development of the remedial constructive trust is largely unnecessary. Apart from that, it's a

pretty good concept.

Perhaps Lord Neuberger has had a change of heart over the last 24 months, or he sees tort adjudication as entirely unlike equity adjudication, or he is being inconsistent as to his fundamental theory of judicial adjudication? Perhaps his is just an example of what happens when judges try to solve problems that are beyond their core professional competency or jurisdiction - Smillie's juristocrat perhaps?

Another link to Vervoort is found in Lord Neuberger's comment about flexible and flabby equity's affront to the common law (by which his Lordship clearly meant judge-made law) of property rights and interests. The Court of Appeal in Vervoort raised as its second potential objection to the constructive trust upon an express trust just this issue - the issue of "property rights at the heart of the trust concept". ${ }^{53}$ Again, the reasoning calls to be set out: ${ }^{54}$

51 See the progression in John Smillie's thought in this respect from his "Formalism, Fairness and Efficiency: Civil Adjudication in New Zealand" [1996] NZ Law Review 254, to "Certainty and Civil Obligation" (2000) 9 Otago LR 633, to "Who Wants Juristocracy?" (2006) 11 Otago LR 183. Jeremy Waldron has commented recently on this in "'Who Wants Juristocracy?' Who Indeed!" in Shelley Griffiths, Mark Henaghan and Marcelo Rodriguez Ferrere (eds) The Search for Certainty: Essays in Honour of John Smillie (Thomson Reuters, Wellington, 2016) 1 at 1.

52 Lord Neuberger, President of the Supreme Court of the United Kingdom "The Remedial Constructive Trust - Fact or Fiction" (paper presented at the 31st Banking Services and Finance Law Association, Conference, Queenstown, 10 August 2014) at [6] (emphasis added). Note this paper is incorrectly attributed to the Banking Services and Finance Law Association; it was presented at the Banking and Financial Services Law Association conference in 2014.

53 Vervoort, above $\mathrm{n} 42$, at [66].

54 Vervoort, above n 42 (emphasis added at [67] save the word "otherwise", citations omitted). 
[66] ... Traditional trust principles provide that the trustee holds the property on behalf of the beneficiaries and so require trustees to not yield trust property to third parties. It can be argued that creation of a constructive trust over express trust assets involves a trustee unilaterally redistributing the property rights at the expense of existing beneficiaries. It has been said:

All of the beneficiaries acting together could have authorised the granting of a beneficial interest to the claimant, but their rights and expectations are not considered in any of the cases.

[67] However, as was pointed out in Murrell v Hamilton, in a successful Lankow v Rose constructive trust claim there will have been contributions to assets of the trust by the claimant, and the trust assets will reflect the value of the contributions. Thus, existing beneficiaries are not being deprived of assets or increases in the value of assets that they would have otherwise enjoyed.

[68] The alternative of allowing the trustees to take advantage of trust principles to deny those who have enriched the trust is not acceptable. As was observed in Hayward v Giordani the function of the courts must be to "develop common law and equity so as to reflect the reasonable dictates of social facts, not to frustrate them". Although remedies against the trustees could be an alternative means of redress, as it has transpired the constructive trust has developed as the primary mechanism of protection. At this stage unjust enrichment concepts have not been developed as an alternative route for partners who are deprived of their contributions to assets in this way. The New Zealand courts had the option of going down that route but have chosen to develop the constructive trust to compensate Lankow $v$ Rose type claimants. In effect, the Lankow $v$ Rose constructive trust prevents an unjust enrichment from occurring. A Lankow $v$ Rose claimant's position is entirely different from that of a contractor. A contractor has a contract and corresponding contractual remedies and the relationship of trust does not arise.

[69] Although there may also be conceptual objections to allowing a trustee to bind the trust with the effect of giving third parties expectations over property held for beneficiaries, in a Lankow $v$ Rose constructive trust there will be contributions to trust property. Those contributions can be expected to be reflected in increases to the value of trust assets or the preservation of value that would otherwise decrease. Equity would not intervene if the effect of recognising a constructive trust would be to reduce the corpus of trust property. It is only the increase or preservation of value corresponding to contributions from the claimant that are to be compensated.

[70] It is acknowledging the reality of the New Zealand trust landscape as it has developed that has justified the recognition of the constructive trust beneficiary's claim. It is a further reality of that landscape that the trustees of family discretionary trusts are more often than not the beneficiaries of those trusts and in control of them. It is common in many trusts in New Zealand "for the settlor to retain some extent of control or to vest that control in someone other than the trustee". The effect is that the reality of a trustee's ability to give a third party expectations (in return for that third party's contributions) over trust property, which that trustee deals with as if their own, must be recognised. There is no misappropriation of property in that the beneficiaries of the express trust have no claim in conscience to the increases in value resulting from the contributions. Beneficiaries cannot expect 
trustees to retain for them an unearned benefit, extracted by expectations engendered by the trustees. The express trust beneficiaries should reasonably expect to yield the third parties an interest.

[71] We see recognising the trustees' ability to hold trust property on behalf of a third party in particular circumstances as a natural application of the Lankow v Rose principles. As noted, those principles go further than the comparable English constructive trust cases. They already partly eschew a traditional property rights analysis as a partner's contribution creates a right against the defendant's property generally, rather than by way of specific proprietary right. A constructive trust over assets held by a trustee, over which he or she has effective control, can be created by the Lankow $v$ Rose factors.

With the greatest respect to the members of the Court, it requires quite a feat of interpretation to characterise the reasoning just quoted as the application of principles, rather than the articulation of policy and hence a use of the law of trusts for instrumental purposes. Now some will see nothing disturbing in that at all. In fact, many working in private law have almost abandoned entirely the notion of private law as a coherent body of rules and principles in favour of a view of private law as public law which the State and its organs use to achieve social and other policy ends. I regret that I believe this to be a serious challenge to the fundamental principle of the rule of law. Whatever specific content we might give that notion, at its heart must lie the idea of taking rights seriously. The assets in question belonging to others (which must be the consequence of the reasoning that the Court had earlier used in denying both the sham and illusory trust arguments) and to impose a constructive trust over those assets in favour of the claimant justified by the unconscionable behaviour of the trustee amounts to a denial of both the (equitable property) rights of the "others" and a contempt of the very same trust the Court had earlier recognised. The answer to this conundrum - provide a remedy to a deserving claimant without demolishing the trust - lay of course in identifying carefully why as against the trustees the claimant was deserving. The Court in my view was getting close in its reference to unjust enrichment. ${ }^{55}$ As stated in my article much more thinking needs to be done about this and it is a cause of regret that the Lankow v Rose trust, itself founded on a bed of justificatory confusion, has been permitted to take on a life which is probably far more embracing of different circumstances than was ever intended or perceived by its authors. Courts should be wary of simply applying Tipping J's formula in Lankow $v$ Rose as a kind of check list without regard to the context in which the invitation to apply it is being delivered.

The Court in Vervoort went on to uphold a Lankow v Rose constructive trust on the express trust on the facts before it, although holding that the quantum of that trust, given that the claimant's contributions were "of a cosmetic nature" and had not "significantly added value", was likely to be significantly less that the claimant had already received by way of settlement with her ex-partner. ${ }^{56}$ What a strange twist indeed!

55 At [68].

56 At [75]. 
As stated the second recent Court of Appeal decision, of a differently constituted bench, was Hawke's Bay Trustee Co Ltd v Judd. In dealing with the constructive trust on an express trust point, the Court was confronted with the argument as to non-delegation of trustees' duties. On the facts the claimant's husband and a corporate trustee were the express trustees, and the corporate trustee's "human face"57 was its accountant and director. The latter had "abjured decision-making responsibilities to the [claimant's husband]". ${ }^{58}$ The Court dismissed the argument by citation of Vervoort: ${ }^{59}$

Reflecting the reality recognised in Vervoort, Mr Hodgkinson treated the property as his own. He was the controlling trustee and as one among a number of family beneficiaries he enjoyed the benefit of an apparently indefinite right to occupy the trust property rent-free. This arrangement was inconsistent with a conventional arm's-length transaction between trustees and a third party to invest or rent trust property to secure an economic return for the beneficiaries. The trustees owned and operated the property for Mr Hodgkinson's primary benefit.

Two comments can be made at this juncture. First, the general background appeal to reality of the trust arrangement and "the reality of the New Zealand trust landscape"60 sustains the instrumentalism I have already identified. Secondly, one might be forgiven for asking whether there was a trust at all given the Court's description of what was involved in the Richard Hodgkinson Trust.

The Court then added an interesting dimension to the non-delegation argument. Although there might have been abjuration of decision-making by one trustee that did not mean his conscience was unaffected. As the Court reasoned:61

[46] We consider it can be said that in the present case the conscience of both trustees is affected. $\mathrm{Mr}$ Hodgkinson obviously had direct knowledge of the contributions being made by Ms Judd but, as the Judge found, Mr Dine had effectively given Mr Hodgkinson "carte blanche" to do as he wished with the assets of the Trust. The requirement for unanimity cannot be used as a shield in this situation where one trustee has abdicated responsibility and so enabled trust property to be improved without first resolving the basis of receipt. Further, although Mr Dine may not have known of these contributions earlier, he did at the time of trial. In all these circumstances, it would be unconscionable not to recognise the benefits freely accepted by the Trust.

57 Hawke's Bay Trustee Co Ltd v Judd, above n 43, at [8].

58 At [38].

59 At [45] (emphasis added).

60 At [44].

61 At [46] (emphasis added, citations omitted). 
It must be recognised however that whether or not it is justifiable to reason that the noninvolved trustee's conscience was bound - and quite what that means is not at all clear, a point made forcefully by the 2016 Law Foundation Visiting Scholar to New Zealand, Professor Graham Virgo, in a public lecture delivered a number of times around the country "Conscience in Equity: A New Utopia"62 - the conclusion in the last sentence of the quote above is simply a non sequitur. The Trust did not freely accept anything; if there was anything unconscionable it was in the trustees acting in an unauthorised manner and the Court's sheeting home the free acceptance to others who simply could not have freely accepted and whose consciences could not have been bound (although Hodgkinson was a beneficiary as well as a trustee, the other beneficiaries were his children and any grandchildren). In sum, it would be unconscionable as against the beneficiary children and grandchildren for the Court to impose a constructive trust.

The second point confronted by the Court when dealing with the constructive trust on an express trust argument was the property rights issue. The Court responded: ${ }^{63}$

[47] The concern about the impact of this approach on the property rights that form a key part of the trust concept is understandable. We make three points on this aspect. First, we agree with Mr Bates' [counsel for the claimant] submission that Ms Judd's successful claim simply reverses or disgorges the benefit of the defendants ' enrichment. This Court in Murrell made the same point. As the Court put it, the claim means "a part of the value of the Trust's property which should not accrue to the Trust does not accrue to it".

[48] Secondly, it was open to the trustees to take steps to preserve the position they now seek to maintain. They could have taken advice on the issue at the time of the marriage. Further, $\mathrm{Mr}$ Hodgkinson could have entered into a relationship property agreement with Ms Judd. Absent such an adjustment of her expectations, where the contributions are to the matrimonial home and the trustees have encouraged or permitted these contributions, it would be wrong to treat a contributor like Ms Judd as a volunteer.

[49] Finally, as Mr Bates also submits, the question is not whether a party's action is in breach of their trustee duties but, rather, the focus is on the reasonableness of a third party's expectation of an interest in the property and the reasonableness of requiring the legal owners to yield an interest or to pay compensation in lieu.

I make a comment on each reason given. The first reason has already been discussed in detail in my article and in my comments on the same reasoning in Vervoort above. I do not regard it as a legitimate justification for circumventing at best and destroying at worst "a key part of the trust

62 Graham Virgo "Conscience in Equity: A New Utopia" (2016 FW Guest Memorial Lecture, University of Otago, Dunedin, 4 August 2016), forthcoming in the Otago Law Review.

63 Hawkes Bay Trustee Co Ltd v Judd, above n 43, at [47]-[49] (citations omitted). 
concept". ${ }^{64}$ The first part of the second reason, while appearing to be intuitively appealing from a practical dimension, is actually I think rather unrealistic. Apart from the expense involved and the general lack of awareness of any right to seek advice or directions, when one stops to think about what the question to be advised upon might actually be, it begins to look rather like bad relationship behaviour counselling. "You might want to live together in a relationship, whereby you both contribute as and where you can to build your relationship, but make sure that, since under Lankow $v$ Rose contributions by either party might lead to acquisition of a constructive trust interest even where the property is already held on an express trust, neither party contributes anything." The second part of the second reason is probably part of the advice the parties would receive. "Just in case you do start making contributions because the natural desire to build a relationship together gets the better of you and you fail to avoid making contributions, it's better to make sure you've entered into an agreement to say that any contributions are being made voluntarily as part of positive partnering rather than towards acquiring any property right." Why is the fact that the property is held in trust not enough to exclude the possibility already?

As to the third reason, I simply cannot accept that an appeal to reasonableness should be enough to justify allowing the impact on property rights of the constructive trust on an express trust. It is difficult to believe that were the general citizenry to understand what was going on - that in effect theft was being sanctioned by the courts - that they would see it as acceptable to be told it was "reasonable". In a world where the state has largely given up on protecting private property in favour of pursuing instrumental objectives, we should perhaps not be too surprised that the courts are joining in. We wait now for the juristocrats to start remaking contracts and reordering gifts.

64 At [47]. 